\title{
Preliminary substrate mixtures including peat moss (Sphagnum magellanicum) for vegetable crop nurseries
}

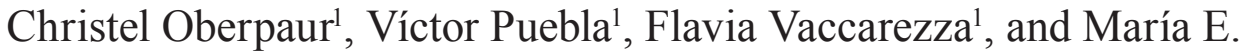 \\ Arévalo ${ }^{2}$ \\ 'Escuela de Agronomía, Universidad Santo Tomás, Ejército 146, Santiago. \\ ${ }^{2}$ Facultad de Ciencias Agropecuarias y Ambientales, Universidad de Las Américas, Manuel Montt 948, \\ Providencia.
}

\begin{abstract}
C. Oberpaur, V. Puebla, F. Vaccarezza, and M.E. Arévalo. 2010. Preliminary substrate mixtures including peat moss (Sphagnum magellanicum) for vegetable crop nurseries. Cien. Inv. Agr. 37(1): 123- 132. Nursery producers grow plants in containers, mainly using substrates based on peat. In order to replace the use of peat, diverse mixtures of substrates combining different proportions of the moss Sphagnum magellanicum Brid. (40, 50 and 60\%) and alternative organic materials, such as compost, humus and composted pine bark, were tested. In the first trial under laboratory conditions, conducted in October 2006, the physicochemical characteristics of nine initial mixtures, including a control, were determined. Five mixtures, with similar physicochemical conditions as the control, and a commercial peat mixture, were selected by the application of Euclidean minimum distances. The finally selected mixtures were three combinations of moss with composted pine bark (60 - 40, 50 - 50 and 40 - 60), a mixture composed of $60 \%$ moss and $40 \%$ humus and a mixture of $60 \%$ moss and $40 \%$ compost. In the second trial, under nursery shade conditions, conducted in December 2006, the selected mixtures were sown with lettuce seeds in a complete randomized block statistical design with six treatments and five replicates. The emergence rate, number of leaves, plant height, canopy weight and root dry weight were evaluated. The results, analyzed by ANOVA and the multiple comparisons test of Duncan ( $\mathrm{p} \leq 0.05)$, indicated that it is feasible to use the mixtures composed of $60 \%$ moss $+40 \%$ humus and $60 \%$ moss $+40 \%$ compost.
\end{abstract}

Key words: Compost, composted pine bark, humus, Lactuca sativa, lettuce, moss, Sphagnum.

\section{Introduction}

The function of a growth substrate is to provide an ideal medium for plantlet germination and emergence (Olguín and Torres, 2003), which allows for the optimal development of plants

Received 26 June 2009. Accepted 18 August 2009. Corresponding author: coberpaur@santotomas.cl during the time they stay in the container (Prat, 1999). A high water storage capacity is necessary due to the limited volume available in small containers. A water availability that fluctuates between 20 to $30 \%$ of the total volume in the growth medium is considered optimal for plant development (OIRSA, 2002). Porosity is also necessary to allow an efficient exchange of oxygen and carbon dioxide (Barceló et al., 2001), which in turn guarantees the plant anchorage (Honorato, 2000). A good substrate must present a density close to $0.22 \mathrm{~g} \mathrm{~mL}^{-1}$ and a stable 
structure hindering contraction of the medium (Ansorena, 1994; FAO, 2002).

There is a large variety of materials available for substrate elaboration, and their selection depends on the vegetal species to be propagated, season, propagation system, price, substrate availability and proper features (Hartmann and Kester, 2002). Potential substrates include organic materials, such as barks, wood chips, compost of diverse origins, coconut fibers, agroindustrial by-products, peat and dehydrated moss (Mollitor et al. 2004). The most used inorganic materials are perlite, rock wool and vermiculite (Honorato and Bonomelli, 1999), which are characterized by a low or null Cationic Interchange Capacity (CIC). Substrate management is simpler when it presents some CIC, since this diminish the risks of nutrient loss by lixiviation caused by frequent irrigation (Ansorena, 1994).

Compost seems to be an excellent alternative to peat (Sandoval and Stuardo, 2001). Composted pine bark presents very variable features, depending on the degree of decomposition and the size and distribution of the particles. Its use is recommended after a high degree of composting; the fresh material presents a high carbon: nitrogen ratio $(\mathrm{C}: \mathrm{N})$ and it may contain substances that are toxic to the plants, such as phenols, resins and tannins (Prat, 1999). The most used substrate for seedbed production, pale peat, offers optimal quality features (Schmilewski, 2008). Fossil peat could stay in peat bogs as a carbon reservoir for thousands of years; however, when it is used as substrate, fossil peat soon becomes an important source of carbon emissions (Gaudig, 2008), calling its use into question.

A possible replacement for peat is fresh biomass of the moss Sphagnum magellanicum (Gaudig and Joosten, 2002), which seems to have similar physical-chemical features to pale peat (Gaudig, 2008). It presents a capacity of water absorption and retention of 17 to $35 \mathrm{~g} \mathrm{~g}^{-1}$ of dry matter (Villarroel et al., 2003), and it is aseptic and an inhibitor of fungi. It is used in horticulture and gardening as an additive to soil or mulch for greenhouse crops, ornamental plants and seedbeds. When mixed with soil, it increases the capacity for water retention and functions as a buffer for changes caused by fertilizer application. It decomposes slowly (Glime, 2007).

Some moss that does not fulfill export requirements accumulates in processing facilities without commercial use; therefore, another application of this resource is significantly interesting. When used as growth medium, moss must have short fibers that allow it to be mixed with other substrates in horticultural nurseries. Hernández (2005) proved that a moss-perlite mixture, with the $\mathrm{pH}$ adjusted with cal dolomite, is inappropriate to ensure the growth of nursery plants, although adequate fertirrigation was applied. The objectives of this study were to formulate substrates for horticultural nurseries that include moss waste and to determine the best mixtures with lettuce as an indicator species.

\section{Materials and methods}

Two tests were carried out; the first was conducted with a preliminary formulation of defined substrate pre-mixtures and mixtures and was carried out in Santiago, and the second consisted of sowing in containers under an awning in the Ecoplants commercial nursery, Talagante, Metropolitan Region, Chile.

The following substrate components were used at different stages: 1. commercial Peat (Sunshine 3 from Sun Gro Horticulture, Canada) based on peat, perlite, cal dolomite, vermiculite and a moisturizing agent; 2. S. magellanicum (S) (Southern Natural Products, Ancud, Chile); 3. Compost (C) (Lombricultura Pachamama, Quillota, Chile); 4. Composted pine bark (CP) (Gromor, Los Ángeles, Chile) and 5. Humus (H) (Lombricultura Pachamama, Quillota, Chile). The $\mathrm{pH}$ values and electric conductivities (EC) of the different components prior to the premixture formulation are indicated in Table 1. 
Table 1. $\mathrm{pH}$ and electric conductivity values of different substratum components used in the formulation of premixtures.

\begin{tabular}{|c|c|c|}
\hline Substratum & $\mathrm{pH}$ & $\begin{array}{c}\mathrm{EC} \\
\mathrm{dS} \mathrm{m}^{-1}\end{array}$ \\
\hline Sphagnum magellanicum & 4.0 & 1.04 \\
\hline Compost & 7.8 & 0.52 \\
\hline Composted pine bark & 6.2 & 0.11 \\
\hline Humus & 6.1 & 0.28 \\
\hline
\end{tabular}

For the second test, coated lettuce seeds of the summer cultivar 'Sahara' (Lactuca sativa var. capitata) were grown in expanded polystyrene trays with 432 cells, each with an individual volume of $10 \mathrm{~cm}^{3}$.

\section{Mixture formulations (Test 1)}

Moss waste and the other substrates were cleaned and sieved to ensure uniform particle size with a sifter with $0.8 \mathrm{~cm}$ openings. Then, nine pre-mixtures were formulated using proportions of 40,50 and $60 \%$ of $S$. magellanicum (S) combined with compost (C), composted pine bark $(\mathrm{CP})$ or humus $(\mathrm{H})$, with five replicates of each combination. In these mixtures, and in the control of commercial peat, four physicalchemical features were analyzed: apparent density $\left(\mathrm{AD}\right.$ in $\left.\mathrm{g} \mathrm{cm}^{-3}\right)$, organic matter $(\mathrm{OM}), \mathrm{pH}$ and electric conductivity (EC).

For the four physical-chemical features, the measurements were made in the supernatant of the solid mixture: deionized water, in a 1:2.5 v/v proportion. The methods proposed by Zadzawka (1990) and Ansorena (1994) were used in the evaluations.

For the selection of the five defined mixtures to be used in the second test, the nine mixtures proposed were compared with the control mixture and with the optimal values reviewed in the literature (Table 3). The method applied was by
Minimum Euclidean distances for each of the premixtures (Mendelhall et al., 1994). The distance between points was measured by the Euclidean distance (d):

$\mathrm{d}(\mathrm{mk}, \mathrm{c})=\sqrt{ } \sum\left(\mathrm{xk}_{1}-\mathrm{c}_{1}\right)^{2}+\left(\mathrm{xk}_{2}-\mathrm{c}_{2}\right)^{2}+\left(\mathrm{xk}_{3}-\mathrm{c}_{3}\right)^{2}+$ $\left(\mathrm{xk}_{4}-\mathrm{c}_{4}\right)^{2}$

where $\mathrm{c}=\left(\mathrm{c}_{1}, \mathrm{c}_{2}, \mathrm{c}_{3}, \mathrm{c}_{4}\right)$ correspond to the $\mathrm{pH}$, $\mathrm{EC}, \mathrm{OM}$ and $\mathrm{AD}$ values of the control the mixture and/or the optimal values; $\mathrm{mk}=\left(\mathrm{xk}_{1}, \mathrm{xk}_{2}\right.$, $\mathrm{xk}_{3}, \mathrm{xk}_{4}$ ) corresponds to the $\mathrm{pH}, \mathrm{EC}, \mathrm{OM}$ and $\mathrm{AD}$ values for the nine different mixtures proposed.

Five combinations with the shortest distances between variables in regard to the control and optimal values were selected (Table 3). These defined mixtures were studied in the second test with indicator plants under the conditions of a commercial nursery. The mixtures selected were analyzed physico-chemically in Agrolab, Santiago, Chile.

Sowing in containers under nursery conditions (Test 2)

On November 29, 2006 the six treatments were mechanically sown with one seed per cell and covered with perlite. Then, the trays were moistened and taken to germination chambers at $25^{\circ} \mathrm{C}$ for three days. After this stage, they were placed under the conditions of the commercial nursery.

The six treatments were the five mixtures, based on volume, selected from test $1: 40 \% \mathrm{~S}$ $+60 \% \mathrm{CP} ; 50 \% \mathrm{~S}+50 \% \mathrm{CP} ; 60 \% \mathrm{~S}+40 \% \mathrm{CP}$; $60 \% \mathrm{~S}+40 \% \mathrm{C} ; 60 \% \mathrm{~S}+40 \% \mathrm{H}$, plus the control treatment of commercial peat. These six treatments were tested with indicator plants. The evaluations were carried out every seven days after sowing, from emergence on. Therefore, five plants were randomly selected from each experimental unit each week, until all the seedbeds were ready to be transplanted. The number of plantlets emerged, plantlet height ( $\mathrm{mm}$ ) measured from the neck base, number of true leaves 
larger than $5 \mathrm{~mm}$ per plant, aerial dry weight and dry root weight were evaluated.

The fertirrigation of the seedlings was done by a sprinkler irrigation system, according to the nursery program, based on the atmospheric demand, until the beginning of dripping under the trays.

\section{Design and statistical analysis}

The statistical design of the second test was in complete random blocks, with six treatments and five replicates. The experimental unit was 144 cells, equivalent to one third of an extended polystyrene tray. The possible existence of differences between treatments was determined by analysis of variance (ANOVA). In the case of significant differences between treatments, the Duncan multiple comparison test was used ( $\mathrm{p} \leq$ 0.05 ). The percentage values were transformed into Bliss degrees before the statistical analysis.

\section{Results}

Physical-chemical evaluations of the premixtures and selection of definite mixtures to be used in the second test (Test 1)

The average values of $\mathrm{pH}, \mathrm{EC}, \mathrm{OM}$ and $\mathrm{AD}$, parameters used in the calculation of the Minimum Euclidian distance, are indicated in Table 2. These results were used as the basis for determining the treatments for further investigation in Test 2. The five mixtures selected by this method were composed of moss and composted pine bark in proportions (v/v) of $60-40,50-50$ and $40-60$, and of $60 \%$ moss $+40 \%$ humus and $60 \%$ moss $+40 \%$ compost. Although this last mixture was not included within the optimal mixtures determined by this methodology of minimum Euclidian distances for each premixture, it was included to establish whether the variables considered in the estimation of this

Table 2. pH, electric conductivity (EC), apparent density (AD) values, Euclidian distances in relation to commercial peat and optimal values of the premixtures.

\begin{tabular}{|c|c|c|c|c|c|c|}
\hline \multirow[b]{2}{*}{ Substratum premixture } & \multirow[b]{2}{*}{$\mathrm{pH}$} & \multirow{2}{*}{$\begin{array}{c}\text { EC } \\
\mathrm{dS} \mathrm{m}^{-1}\end{array}$} & \multirow{2}{*}{$\begin{array}{c}\mathrm{OM} \\
\%\end{array}$} & \multirow{2}{*}{$\begin{array}{c}\mathrm{AD} \\
\mathrm{g} \mathrm{cm}^{-3}\end{array}$} & \multicolumn{2}{|c|}{ Euclidian distance } \\
\hline & & & & & $\mathrm{Cpm}^{1}$ & $\mathrm{Ov}^{2}$ \\
\hline $\mathrm{Cpm}$ & 5.70 & 1.00 & 69.5 & 0.13 & & \\
\hline $\mathrm{S} 40 \mathrm{C} 60^{3}$ & 6.04 & 0.61 & 47.0 & 0.21 & 22.49 & 32.98 \\
\hline S50 C50 & 5.89 & 0.59 & 50.4 & 0.16 & 19.16 & 29.65 \\
\hline $\mathrm{S} 60 \mathrm{C} 40^{4 *}$ & 5.61 & 0.60 & 56.5 & 0.12 & 13.06 & 23.55 \\
\hline S40 CP60* & 5.87 & 0.33 & 59.5 & 0.21 & 10.03 & 20.52 \\
\hline S50 CP50* & 5.69 & 0.29 & 61.0 & 0.16 & 8.52 & 19.00 \\
\hline S60 CP40* & 5.40 & 0.24 & 63.3 & 0.11 & 6.29 & 16.76 \\
\hline S40 H60 & 5.59 & 0.30 & 42.3 & 0.25 & 27.21 & 37.71 \\
\hline $\mathrm{S} 50 \mathrm{H} 50$ & 5.55 & 0.33 & 44.9 & 0.17 & 24.61 & 35.11 \\
\hline S60 H40* & 5.29 & 0.32 & 46.4 & 0.14 & 23.09 & 33.59 \\
\hline
\end{tabular}

${ }^{1} \mathrm{Cpm}$ : commercial peat mixture.

${ }^{2}$ Ov: optimal values proposed by Ansorena (1994) and FAO (2002).

${ }^{3}$ S: Sphagnum moss CP: composted pine bark C: compost $\mathrm{H}$ : humus.

* Selected mixtures used in trial 2 , under nursery conditions. 
Table 3. Influence of different substrate mixtures including Sphagnum moss on lettuce seed emergence (\%)

\begin{tabular}{lcccr}
\hline & \multicolumn{3}{c}{ Days after sowing } \\
\cline { 2 - 4 } Treatments & 7 & 14 & 21 & 28 \\
\hline Cpm $^{1}$ & $95.4 \mathrm{a}^{2}$ & $97.8 \mathrm{a}$ & $98.3 \mathrm{a}$ & $98.5 \mathrm{a}$ \\
S40 CP60 & $92.4 \mathrm{~b}$ & $93.9 \mathrm{~d}$ & $94.7 \mathrm{~b}$ & $94.7 \mathrm{~b}$ \\
S50 CP50 & $93.5 \mathrm{~b}$ & $94.2 \mathrm{~cd}$ & $95.3 \mathrm{~b}$ & $95.3 \mathrm{~b}$ \\
S60 CP40 & $93.8 \mathrm{~b}$ & $95.6 \mathrm{bc}$ & $95.6 \mathrm{~b}$ & $95.6 \mathrm{~b}$ \\
S60 C40 & $95.1 \mathrm{a}$ & $96.7 \mathrm{~b}$ & $98.3 \mathrm{a}$ & $98.3 \mathrm{a}$ \\
S60 H40 & $93.8 \mathrm{~b}$ & $96.5 \mathrm{~b}$ & $97.8 \mathrm{a}$ & $98.3 \mathrm{a}$ \\
\hline
\end{tabular}

${ }^{1} \mathrm{Cpm}$ : commercial peat mixture.

${ }^{2}$ Means followed by the same letter in the column indicate no statistical differences between treatments, according to Duncan $(\mathrm{p}=0.05)$.

${ }^{3}$ S: Sphagnum moss; CP: composted pine bark; C: compost H: humus.

method present an analogy to growth and development evaluations.

Sowing in containers under nursery conditions (Test 2)

The average rates of emergence for the plantlets under the different treatments tested are shown in Table 3. At 21 days after sowing (days), when the emergence values were stabile, the only significant differences observed were between the control treatment and the treatments with the moss and composted pine bark substrate.

Starting at 14 days, significant differences were detected in the number of leaves for plants grown in the control substrate of commercial peat (control treatment), which had 1.8 leaves per plant, and those grown in the $60 \%$ moss $+40 \%$ humus substrate, which had 1.5 leaves per plant. Plants grown under the other treatments averaged 1.1 leaves per plant. At 28 days, the highest number of leaves was obtained in the commercial peat control with 5.1 leaves per plant, followed by the treatments of $60 \%$ moss $+40 \%$ humus and $60 \%$ moss $+40 \%$ compost with 4.7 and 4.6 leaves per plant, respectively. The low values obtained in the mixtures composed of moss with 60 or $50 \%$ composted pine bark (4.2 and 4.0 leaves per plant, respectively) were virtually constant during the test. When the volume of composted pine bark was decreased to $40 \%$ of the mixture, the number of leaves per plant increased to 4.4.

The effect of the treatments on the height of lettuce plantlets is shown in Table 4. After 14 days, the treatments resulting in the greatest plantlet heights were the control of commercial peat and the mixture of humus and moss. The worst results were found with the mixtures of composted pine bark and moss.

Table 4. Influence of different substrate mixtures on lettuce growth.

\begin{tabular}{|c|c|c|c|c|}
\hline \multirow[b]{2}{*}{ Treatment } & \multicolumn{4}{|c|}{ Lettuce plant height, $\mathrm{mm} \cdot$ plant $^{-1}$, after sowing } \\
\hline & 7 days & 14 days & 21 days & 28 days \\
\hline $\mathrm{Cpm}^{1}$ & $14.4 \mathrm{a}^{2}$ & $22.6 \mathrm{a}$ & $46.0 \mathrm{a}$ & $111.0 \mathrm{a}$ \\
\hline $\mathrm{S} 40 \mathrm{CP} 60^{3}$ & $9.6 \mathrm{~d}$ & $15.5 \mathrm{c}$ & $30.1 \mathrm{c}$ & $90.3 \mathrm{~b}$ \\
\hline S50CP50 & $9.2 \mathrm{~d}$ & $15.4 \mathrm{c}$ & 29. c & $79.0 \mathrm{c}$ \\
\hline $\mathrm{S} 60 \mathrm{CP} 40$ & $9.4 \mathrm{~d}$ & $15.5 \mathrm{c}$ & $30.9 \mathrm{c}$ & $83.3 \mathrm{c}$ \\
\hline $\mathrm{S} 60 \mathrm{C} 40$ & $12.7 \mathrm{c}$ & $18.3 \mathrm{~b}$ & $43.0 \mathrm{~b}$ & $106.0 \mathrm{a}$ \\
\hline S60H40 & $13.6 \mathrm{~b}$ & $21.9 \mathrm{a}$ & $46.1 \mathrm{a}$ & $109.0 \mathrm{a}$ \\
\hline
\end{tabular}

${ }^{1} \mathrm{Cpm}$ : commercial peat mixture.

${ }^{2}$ Means followed by the same letter in the column indicate no statistical differences between treatments, according to Duncan ( $\mathrm{p}=0.05$ ).

${ }^{3}$ S: Sphagnum moss; CP: composted pine bark; C: compost H: humus. 
Significant differences in the canopy dry weight were found for the different treatments (Table 5). At 7 days, the highest weight, $4.7 \mathrm{mg}$ plant $^{-1}$, was obtained with the control treatment. The moss + humus and moss + compost treatments resulted in weights of 4.0 and $3.9 \mathrm{mg} \mathrm{plant}^{-1}$, respectively; these weights were not significantly different than those for the controls. The worst results corresponded to the treatments including composted pine bark and moss in different proportions. From 14 days and until 21 days, the control of commercial peat and the humus + moss mixture allowed higher canopy dry weights in lettuce plantlets, without any significant differences among them. On the other hand, the lowest canopy dry weights resulted from the mixtures including composted pine bark. At 28 days, the lowest values corresponded to the moss + pine bark treatments, while the control treatment continued to yield the highest aerial dry weight.

At 28 days, plants grown in the control of commercial peat and $60 \%$ moss $+40 \%$ humus mixture $(\mathrm{S} 60 \mathrm{H} 40)$ presented significantly higher radical dry weights with $90.11 \mathrm{mg}^{\text {plant }}{ }^{-1}$ and $89.54 \mathrm{mg} \mathrm{plant}^{-1}$, respectively, than those grown under the other treatments (Table 3). In the three treatments including composted pine bark, the lowest weights were obtained from 14 days to the end of the experiment.

\section{Discussion}

In substrates with a $\mathrm{pH}$ close to 5.3 , as in the case of the mixtures composed of $60 \%$ moss $+40 \%$ humus and $60 \%$ moss $+40 \%$ pine bark (Table 2), a phosphorous deficiency might occur (Muñoz, 2001). All the remaining mixtures are within the $\mathrm{pH}$ range of 5.5-6.5 considered appropriate by Ansorena (1994) and FAO (2002). The substrates with a $\mathrm{pH}$ between 5.5 and 6.8 are considered weakly acidic, favoring the availability of nutrients for the vegetables (Hartmann and Kester, 2002). According to Munita (2001), primary nutrients (nitrogen, phosphorous and potassium) as well as secondary elements (sulfur, calcium and magnesium), are more available at $\mathrm{pH}$ 5.5-6.5 for substrates of organic and mineral origin. On the contrary, secondary elements as iron, manganese, chlorine and zinc are less available in this $\mathrm{pH}$ range.

The plants may grow without restrictions in the wide interval of $\mathrm{pH} 4$ to 8 , as long as the concentrations of available nutrients are sufficient. In organic substrates, the optimal $\mathrm{pH}$ range for plant growth is between 5.0 and 5.5, although plants may grow satisfactorily at $\mathrm{pH}$ values outside this interval (Ansorena, 1994).

The lettuce plant accepts $\mathrm{pH}$ levels between 5.5 and 7.0 but grows best between 6.0-6.8 (Sobrino and Sobrino, 1994). According to the descriptions by these authors, it may be inferred that the mixture composed of $40 \%$ moss and $60 \%$ compost would be the best in meeting this $\mathrm{pH}$ demand.

As a consequence of the reduced volume of medium available to plants cultivated in containers, the concentration of mineral elements in the aqueous solution is usually higher than for field-grown crops; thus, there is an increased risk of accumulation of dissolved salts (Ansorena, 1994). According to OIRSA (2002), salinity is present due to an excessive contribution of mineral nutrients from fertilization, irrigation water or the presence of high concentrations of salts in some substrates, in regard to the amounts absorbed by the plant and losses by lixiviation. Table 2 summarizes the average EC values of the different premixtures. It may be observed that the highest EC values are presented by the mixtures formulated with moss and compost. All the EC values for the mixtures proposed are less than the range of $0.75-2.0 \mathrm{dS} \mathrm{m}^{-1}$ considered optimal by OIRSA (2002) for seedbeds and trays. These low values might affect the contribution of nutrients to the plantlets (Cáceres and Marfa, 2003). The mixture of commercial peat is within the optimal range of electric conductivity. 
Organic matter is necessary for maintaining a good soil structure because it acts as a granulator, increasing the capacity of cationic interchange and thereby reducing the loss by lixiviation of elements as potassium, calcium and magnesium. In addition, it improves water retention and supply in the soil (Tisdale and Nelson, 1982). Muñoz (2001), adds that the absorbancy capacity of the soil improves with the presence of this element, and minerals, which may be used by the plants, are released through its decomposition.

The highest amounts of $\mathrm{OM}$ are in the mixtures composed of composted pine bark and moss, followed by the mixtures of compost and moss. The lowest values are shown in the mixtures of moss and humus. All the mixtures proposed contain less than the optimal value, higher than $80 \%$, of OM proposed by Ansorena (1994) and FAO (2002). According to Prat (1999), the substrates with a high OM content and low biological stability are more subject to microbial degradation, which may increase $\mathrm{CO}_{2}$ release and affect the water and mineral absorption by the roots.

Apparent density of the soil is important for substrate management, since it reflects compaction and allows inference of difficulties in emergence and rooting as well as water and air circulation (Porta et al., 1999). When the apparent density of a substrate is higher, the probability of compaction and mechanical resistance to rooting is higher (Honorato, 2000).

The apparent density values of the mixtures containing $40 \%$ moss and $60 \%$ of compost, humus or composted pine bark (Table 2) are relatively close to the desired value of $0.22 \mathrm{~g} \mathrm{~cm}^{-3}$, proposed by Ansorena (1994) and FAO (2002).
The scarce seedling emergence observed with the moss and pine bark mixtures might be a consequence of the high moisture retention by the composted pine bark (Gardiazabal, 1994) and moss. This undesirable condition might cause low oxygen availability (anoxia), which increases the ethylene levels in the seed, resulting in delayed germination and further emergence of the lettuce plantlets (Tapia, 1998).

The plantlets growing in the substrates containing composted pine bark presented the lowest numbers of leaves, which might indicate that the treatments based on moss and composted pine bark affect the development of lettuce plantlets. This negative effect may be due to the low EC values observed, which negatively influence the contribution of nutrients to the plant (Fuentes, 1999).

The high values observed (Table 5) during the entire test in the control treatment might be explained by the commercial mixture of peat. In addition to contain organic matter, humic acids and hormones, this mixture has the property of diminishing the effects of some inhibiting substances of growth commonly found in soil and in some substrates of organic origin (Penningsfeld and Kurzmann, 1983). On the other hand, Acevedo (1996), indicates that carbonates, a moisturizing agent and also a formulation based on fertilizers are added to this mixture to adjust the $\mathrm{pH}$. Like the control, the treatments with $60 \%$ moss as a base plus $40 \%$ of an alternative substrate (humus or compost) obtained promising results during the test. According to Prat (1999), the low values presented by the mixtures of moss and composted pine bark might be due to the phenols, resins, terpenes and tannins, substances toxic to vegetables, that are present in pine bark with a low level of composting. 
Table 5. Influence of the substrate mixture on lettuce dry weight

\begin{tabular}{lcccc}
\hline & \multicolumn{5}{c}{ Days after sowing } \\
\cline { 2 - 5 } Treatments & 7 & 14 & 21 & 28 \\
\hline & & & & \\
Canopy dry weight, mg plant & & & & \\
Cpm $^{1}$ & $4.71 \mathrm{a}^{2}$ & $22.82 \mathrm{a}^{2}$ & $55.60 \mathrm{a}^{2}$ & $98.76 \mathrm{a}^{2}$ \\
S40 CP60 & $2.45 \mathrm{c}$ & $10.21 \mathrm{c}$ & $30.52 \mathrm{c}$ & $56.50 \mathrm{de}$ \\
S50 CP50 & $1.92 \mathrm{~d}$ & $7.41 \mathrm{~d}$ & $29.33 \mathrm{c}$ & $52.62 \mathrm{e}$ \\
S60 CP40 & $2.35 \mathrm{~cd}$ & $9.52 \mathrm{~cd}$ & $32.59 \mathrm{c}$ & $59.25 \mathrm{~d}$ \\
S60 C40 & $3.89 \mathrm{~b}$ & $18.54 \mathrm{~b}$ & $50.02 \mathrm{~b}$ & $88.44 \mathrm{c}$ \\
S60 H40 & $4.04 \mathrm{~b}$ & $20.91 \mathrm{a}$ & $53.94 \mathrm{a}$ & $93.94 \mathrm{~b}$
\end{tabular}

Root dry weight, mg plant ${ }^{-1}$

\begin{tabular}{lccrc}
$\mathrm{Cpm}^{1}$ & $4.65 \mathrm{a}^{2}$ & $16.56 \mathrm{~b}^{2}$ & $35.21 \mathrm{ab}^{2}$ & $90.11 \mathrm{a}^{2}$ \\
$\mathrm{~S} 40 \mathrm{CP} 60^{3}$ & $2.22 \mathrm{~d}$ & $10.54 \mathrm{~d}$ & $25.21 \mathrm{c}$ & $58.41 \mathrm{c}$ \\
$\mathrm{S} 50 \mathrm{CP} 50$ & $1.52 \mathrm{e}$ & $08.91 \mathrm{~d}$ & $22.21 \mathrm{c}$ & $55.51 \mathrm{c}$ \\
$\mathrm{S} 60 \mathrm{CP} 40$ & $2.63 \mathrm{~cd}$ & $09.51 \mathrm{~d}$ & $24.32 \mathrm{c}$ & $60.52 \mathrm{c}$ \\
$\mathrm{S} 60 \mathrm{C} 40$ & $3.03 \mathrm{c}$ & $13.44 \mathrm{c}$ & $36.21 \mathrm{a}$ & $84.33 \mathrm{~b}$ \\
$\mathrm{~S} 60 \mathrm{H} 40$ & $3.94 \mathrm{~b}$ & $18.63 \mathrm{a}$ & $33.43 \mathrm{~b}$ & $89.54 \mathrm{a}$ \\
\hline
\end{tabular}

${ }^{1} \mathrm{Cpm}$ : commercial peat mixture.

${ }^{2}$ Means followed by the same letter in each column indicate no statistical differences between treatments, according to Duncan $(\mathrm{p}=0.05)$.

${ }^{3} \mathrm{~S}$ : Sphagnum moss; CP: composted pine bark; C: compost $\mathrm{H}$ : humus. Number denotes the proportion of each component in the mixture.

The increase in canopy dry weight of lettuce plantlets grown in the control, $60 \%$ moss $+40 \%$ humus and $60 \%$ moss $+40 \%$ compost treatments over time is shown in Table 5. The treatment control had the most canopy and radical growth at 28 days. Zumaeta and Arancibia (1993) indicate that peat presents a variety of hormones, auxin (indoleacetic acid) among them, that favor the vegetative growth of plants. The organic matter contained in peat includes heteroauxins, which foster root formation (Penningsfeld and Kurzmann, 1983).
In summary, it is feasible to use organic materials as an alternative to peat for the production of seedlings in agriculture. The mixtures composed of $60 \%$ moss combined with $40 \%$ humus or compost are potentially growth media that are adequate for horticultural plants in containers, due to their physico-chemical features. An improvement is necessary and can probably be accomplished by the inclusion of nutrients in their formulation. 


\section{Resumen}

\section{Oberpaur, V. Puebla, F. Vaccarezza y M.E. Arévalo. 2010. Formulación preliminar de mezclas de sustratos en base a musgo (Sphagnum magellanicum) para viveros hortícolas.} Cien. Inv. Agr. 37(1):123-132. Los productores de plantines hortícolas en contenedores utilizan principalmente sustratos basados en turba. Con el objetivo de reemplazar la turba, se evaluaron mezclas de sustratos que incluyen al musgo (Sphagnum magellanicum Brid.) y materiales orgánicos alternativos (compost, humus, corteza de pino compostada). En un primer ensayo, Octubre 2006, se determinaron características fisicoquímicas de nueve premezclas iniciales, además de un control de turba comercial. Las premezclas se obtuvieron mediante la combinación de musgo en proporciones 60,50 y 40\%, con un sustrato complementario como compost, corteza de pino o humus, en proporciones 40, 50 y 60\%. Se eligieron las cinco mezclas de condiciones fisicoquímicas similares al control, a través de distancias mínimas euclidianas, para luego ensayarlas con plantas indicadoras. Las mezclas seleccionadas fueron tres combinaciones entre musgo y corteza de pino (60-40, 50-50, 40-60), una mezcla compuesta por $60 \%$ de musgo y $40 \%$ de humus y otra con $60 \%$ de musgo y $40 \%$ de compost. El segundo ensayo, Diciembre 2006, se efectuó bajo sombreadero, en un vivero comercial. Se sembraron con lechuga las mezclas seleccionadas, en un diseño estadístico de bloques completos al azar con 5 tratamientos, más el control, y 5 repeticiones. Se midieron las variables emergencia, cantidad de hojas, altura de plántulas, peso seco aéreo y radical. Los resultados se sometieron a análisis de varianza y a la prueba de comparaciones múltiples de Duncan $(\mathrm{p} \leq 0.05)$ en caso de detectar diferencias significativas. Los resultados indicaron que es factible utilizar como materiales alternativos para la producción de plántulas en contenedores, mezclas compuestas por un $60 \%$ musgo y $40 \%$ humus; $60 \%$ musgo y $40 \%$ compost.

Palabras clave: Compost, corteza de pino compostada, humus, Lactuca sativa, lechuga, musgo, Sphagnum.

\section{References}

Acevedo, M. 1996. Análisis técnico económico de un sistema de producción de plántulas hortícolas bajo un sistema tecnificado. Memoria Lic. Ing. Administración de Agronegocios. Facultad de Ciencias Económicas y Administrativas, Universidad Central, Santiago, Chile. 130 pp.

Ansorena, M. J. 1994. Sustratos propiedades y caracterización. Ediciones Mundi-Prensa, Madrid, España. 172 pp.

Barceló, J., G. Nicolas, B. Sabater, and R. Sánchez. 2001. Fisiología vegetal. Ediciones Pirámide, Madrid, España. 556 pp.

Cáceres R., and O. Marfa. 2003. Sustratos y fertilidad en ornamentales de exterior. Revista Horticultura 39: 14-21. www.fertiberia.com. Accessed: February, 2009).

FAO. 2002. El cultivo protegido en clima mediterráneo. Medios y técnicas de producción. Estudios FAO: Producción y Protección Vegetal 90. Ofi- cina Regional para América Latina y el Caribe. www.fao.org . (Accessed: February, 2009).

Fuentes, J. 1999. El suelo y los fertilizantes. Quinta edición. Ediciones Mundi-Prensa, Madrid, España. $352 \mathrm{pp}$.

Gardiazabal, F. 1994. Nuevas técnicas de propagación y sistemas de plantación y productividad en cítricos. Publicación Técnica $\mathrm{N}^{\circ}$ 3. Sociedad Agronómica de Chile. Santiago, Chile. 61 pp.

Gaudig, G. 2008. Sphagnum farming in progressexperiences and perspectives. Proceedings of the $13^{\text {th }}$ International Peat Congress. After Wise Use - The Future of Peatlands. Tullamore, Ireland.

Gaudig, G., and H. Joosten. 2002. Peat moss (Sphagnum) as a renewable resource-an alternative to Sphagnum peat in Horticulture? Pages 17-125. In: G. Schmilewsk, and L.Rochefort (eds.). Proceedings of the International Peat Symposium: Peat in Agriculture-Quality and Environmental Challenges. A joint symposium of Comission II (Industrial utilization of peat and peatlands) and Comission V (After-use of cut-over peatlands) of 
the International Peat Society. Pärnu, Estonia.

Glime, J.M. 2007. Economic and ethnic uses of Bryophytes. Pages 14-41. In: Zander REA (ed.). Flora of North America. Vol. 27. Oxford University Press, NY, USA.

Hartmann, H., and D. Kester. 2002. Propagación de plantas. Principios y prácticas. Ediciones Continental. México. 760 pp.

Hernández, J. 2005. Análisis y Evaluación de Sustratos en Base a Sphagnum Moss Utilizados en la Producción de Plantines de Lechuga (Lactuca sativa var. capitata L.) y Pimiento (Capsicum annuum L.). Tesis de Licenciatura Ing. Agr. Escuela de Agronomía, Universidad Santo Tomás. Santiago, Chile. 85 pp.

Honorato, R. 2000. Manual de Edafología. Ediciones Universidad Católica de Chile, Santiago, Chile, $241 \mathrm{pp}$.

Mendelhall, W.D., and R. Wackerly. 1994. Estadística Matemática con Aplicaciones. Ediciones Iberoamericano. México, D.F. 325 pp.

Mollitor, H., A. Faber, R. Marutzky, and S. Springer. 2004. Peat substitute on the basis of recycled wood chipboard. Acta Horticulturae 644: 123130 .

Munita, J. 2001. Características y clasificación de los suelos. En: Sociedad Química y Minera de Chile S.A. Agenda del Salitre. Undécima Edición. Santiago, Chile. 1515 pp.

Muñoz, J. 2001. Evaluación de la producción de plántulas de clavel a partir de semillas en dos sustratos mezclados en cuatro proporciones diferentes, en la Comuna de Quilpue, V Región, Chile. Tesis. Lic. Ing. Agr. Escuela de Agronomía, Universidad del Mar. Viña del Mar, Chile. 62 pp.

OIRSA 2002. Producción de sustratos para viveros. Organismo Internacional Regional de Sanidad Agropecuaria. www.oirsa.org. (Accessed: May, 2006).

Olguín, G., and S. Torres. 2003. Producción de almácigos en cultivos hortícolas. Instituto de Investigación Agropecuarias, Centro Regional de
Investigación La Platina. Santiago, Chile, 23 pp. Penningsfeld, F., and P. Kurzmann. 1983. Cultivos Hidropónicos y en Turba. Segunda ed. Editorial Mundiprensa. Madrid, España. 343 pp.

Porta, J., M. López-Acevedo, and C. Roquero. 1999. Edafología para la agricultura y el medio ambiente. Segunda edición. Ediciones Mundi-Prensa, Madrid, España. 849 pp.

Prat, L. 1999. Sustratos para propagación, recipientes y sustancias enraizantes. Facultad de Ciencias Agronómicas. Ediciones Universidad de Chile, Santiago, 58 pp.

Sandoval, A., and A. Stuardo. 2001. El compost; una buena alternativa. Centro de Semillas de Árboles Forestales. Facultad de Ciencias Forestales. Universidad de Chile. www.uchile.cl. (Accessed: Jun, 2006).

Schmileski, G. 2008. The role of peat in assuring the quality of growing media. Mires and Peat 3, article 02. International Mire Conservation Group and International Peat Society. www.mires-andpeat.net. (Accessed: February, 2009).

Sobrino, I.E., and V.E. Sobrino. 1994. Tratado de horticultura herbácea. Hortalizas de hoja, raíz y hongos. Editorial Aedos, Barcelona, España. 313 pp.

Tapia, M.L. 1998. Producción intensiva hidropónica de lechugas. Páginas 42-47. En: Seminario Nacional sobre Hidroponía. 28-29 de Mayo. FAO. Santiago, Chile.

Tisdale, S., and W. Nelson. 1982. Fertilidad de los Suelos y Fertilizantes. Ediciones Uteha, México, $760 \mathrm{pp}$.

Villarroel, M., C. Acevedo, E. Yáñez, and E. Biolley. 2003. Propiedades funcionales de la fibra del musgo Sphagnum magellanicum y su utilización en la formulación de productos de panadería. Arch. Latinoamer. Nutr. 53:400-407.

Zumaeta, A., and A. Arancibia. 1993. Horticultura Ornamental. Guía de Sustratos. Facultad de Agronomía, Universidad Católica de Valparaíso. Quillota. Chile. 70 pp. 